\title{
KOMPETENSI PENGADILAN TINDAK PIDANA KORUPSI DALAM MENGADILI TINDAK PIDANA PENCUCIAN UANG
}

\author{
THE COMPETENCE OF THE COURTS OF CRIMINAL ACTS \\ OF CORRUPTION IN PROSECUTING THE CRIME OF MONEY \\ LAUNDERING
}

\author{
Edward Samosir \\ Hakim Tipikor Provinsi NTB \\ email : samo.one2807@gmail.com \\ Naskah diterima : 05/10/2016; revisi : 28/12/2016; disetujui : 30/12/2016
}

\begin{abstract}
The extension on the authority of the Court of corruption in prosecuting money laundering should be regulated in an Act. To ensure legal certainty, the prosecutors on the State Attorney or on the Corruption Eradication Commission (KPK) as the competent institutions demanding money laundering in the delegate a case to corruption court should be accompanied by an indictment that include underlying predicate offenses "Corruption" as Article 2 letter " $a$ " of Law No. 8 of 2010 on the prevention and combating of money laundering. The revision of Article 69 of Law No. 8 of 2010 on the prevention and combating of money laundering as a legal basis for the transfer of a case to court is unclear norm. This article will elaborate legal implication of authority of the Court of corruption in judging of money laundering action.
\end{abstract}

Keywords: Crime, Money Laundering

Abstrak

Adanya perluasan kewenangan Pengadilan tindak pidana Korupsi dalam mengadili tindak pidana pencucuian uang harus diatur dalam Undang-Undang,. Untuk menjamin kepastian hukum, maka Penuntut Umum pada Kejaksaan atau Komisi Pemberantasan Korupsi (KPK) sebagai lembaga yang berwenang menuntut tindak pidana pencucian uang dalam melimpahkan perkara ke pengadilan tindak pidana korupsi harus disertai surat dakwaan yang mengikutkan tindak pidana asalnya "Korupsi". Revisi Pasal 69 Undang-Undang Nomor 8 Tahun 2010 tentang pencegahan dan pemberantasan tindak pidana pencucian uang sebagai dasar hukum pelimpahan perkara ke pengadilan adalah merupakan norma kabur. Artikel ini akan membahas tentang implikasi hukum kompetensi pengadilan tindak pidana korupsi dalam mengadili tindak pidana pencucian uang.

Kata kunci:Tindak Pidana, Pencucian uang

\section{PENDAHULUAN}

Tindak Pidana pencucian uang (money laundering) merupakan suatu fenomena universal yang melekat dan telah menjadi bagian dari sejarah peradaban umat manusia semenjak berabad-abad yang lampau. Hampir tidak ada satu negara pun di dunia ini, baik negara maju maupun negara berkembang yang steril dari tindak pidana pencucian uang sehingga bentuk kejahatan ini dikategorikan sebagai sebagai kejahatan serius (serious crime) dan bahkan bersifat transnasional (transnational crime).

Indonesia baru memandang praktek pencucian uang sebagai suatu tindak pidana dan menetapkan sanksi bagi pelakunya adalah ketika diundangkan nya UU No 15 Tahun 2002 tentang Pencucian Uang (UUPU), kemudian pada tanggal 17 April 2002 diubah dengan UU Nomor 
25 Tahun 2003 tentang pencucian uang. Sebagai negara yang berdaulat, Pemerintah mempunyai kekuasaan dan kewajiban untuk mengatur peri kehidupan warga negaranya. Kedaulatan pemerintahan diperlukan sebagai dasar terlaksananya jalannya pemerintahan baik itu di bidang ekonomi, hukum, politik, sosial, budaya, dan berbagai segi kehidupan lainnya.

Penanganan tindak pidana pencucian uang di Indonesia dimulai sejak disahkannya Undang-undang Nomor 15 tahun 2002 tentang tindak pidana Pencucian uang sebagaimana telah diubah dengan Undang-undang Nomor 25 tahun 2003 tentang Perubahan atas Undangundang Nomor 15 tahun 2002 tentang Tindak Pidana Pencucian Uang, namun upaya yang dilakukan tersebut dirasakan belum optimal, antara lain karena peraturan perundang-undangan yang ada ternyata masih memberikan ruang timbulnya penafsiran yang berbeda-beda., Hal ini terlihat dari adanya celah hukum berupa, kurang tepatnya pemberian sanksi, belum dimanfaatkannya pergeseran beban pembuktian, keterbatasan akses informasi, sempitnya cakupan pelapor dan jenis laporannya, serta kurang jelasnya tugas dan kewenangan dari pelaksana Undangundang ini. ${ }^{1}$ Untuk memenuhi kepentingan nasional dan menyesuaikan standar internasional, tanggal 22 Oktober 2010 telah diundangkan Undang-undang Nomor 8 tahun 2010 tentang pencegahan dan pemberantasan tindak pidana pencucian uang sebagai pengganti Undang-undang 15 tahun 2002 tentang tindak pidana Pencucian uang sebagaimana telah diubah dengan Undang-Undang Nomor 25 tahun 2003 tentang perubahan atas UndangUndang Nomor 15 tahun 2002 tentang tindak pidana Pencucian uang.

Untuk melakukan upaya pencegahan dan pemberantasan tindak pidana pencucian

\footnotetext{
1 Undang-Undang Nomor 8 tahun 2010 tentang pencegahan dan pemberantasan tindak pidana pencucian Uang.
}

uang ini, pada bagian menimbang huruf $\mathrm{b}$ Undang-Undang No. 8 Tahun 2010 tentang pencegahan dan pemberantasan tindak pidana pencucian uang, jelas dinyatakan "bahwa pencegahan dan pemberantasan tindak pidana pencucian uang memerlukan landasan hukum yang kuat untuk menjamin kepastian hukum, efektivitas penegakan hukum, serta penelusuran dan pengembalian harta kekayaan hasil tindak pidana korupsi".

Usaha untuk menciptakan landasan hukum dalam pencegahan dan pemberantasan tindak pidana pencucian uang ini, tidak bisa dilepaskan dari substansi hukum pidana materiil dan formil. Hukum pidana formil (Hukum Acara) ini mencakup juga mengatur kompetensi suatu peradilan dalam menangani suatu perkara. Tujuan dari hukum acara pidana adalah untuk mencari dan mendapatkan atau setidak-tidaknya mendekati kebenaran materiil, yaitu kebenaran yang selengkaplengkapnya dari suatu perkara pidana dengan menetapkan ketentuan hukum acara pidana secara jujur dan tepat, dengan tujuan untuk mencari siapakah pelaku yang dapat didakwakan melakukan suatu pelanggaran hukum, dan selanjutnya meminta pemeriksaan dan putusan dari pengadilan guna menentukan apakah orang yang didakwa itu dapat dipersalahkan. ${ }^{2}$

Dalam Undang-undang Undang-Undang No 2 Tahun 1986 tentang peradilan umum sebagaimana telah diubah dengan UndangUndang Nomor 8 Tahun 2004 tentang Perubahan Atas Undang-Undang Nomor 2 Tahun 1986 tentang Peradilan Umum sebagaimana diubah kembali dengan Undang-Undang No. 49 tahun 2009, dalam Pasal 51 dinyatakan: "Pengadilan Negeri bertugas dan berwenang memeriksa, memutus, dan menyelesaikan perkara pidana dan perkara perdata di tingkat

${ }^{2}$ Redaksi Bumi Aksara, KUHAP Lengkap, Bumi Aksara, Jakarta, 2001, hal. 204 
pertama". ${ }^{3}$ Mengacu kepada Pasal 51 tersebut, maka dapatlah disimpulkan kewenangan pengadilan negeri dalam mengadili perkara hanya ditentukan jenis perkara, yang dalam hal ini adalah Pidana dan Perdata.

Sebelum lahirnya undang-undang Nomor 8 Tahun 2010 tentang pencegahan dan pemberantasan tindak pidana pencucian uang, telah diundangkan Undang-undang Nomor 46 Tahun 2009 tentang Pengadilan Tindak pidana korupsi dan UndangUndang Nomor 48 Tahun 2009 tentang kekuasaan kehakiman, yang didalam kedua undang-undang tersebut mengatur terkait kompetensi pengadilan dalam mengadili tindak pidana pencucian uang.

Undang-undang Nomor 8 Tahun 2010 tentang pencegahan dan pemberantasan tindak pidana pencucian uang adalah Undang-undang yang bersifat khusus yang mengatur perbuatan yang memenuhi unsurunsurtindakpidanadenganketentuandalam Undang-Undang ini, dan untuk mengadili perkara terhadap setiap orang yang diduga sebagai pelaku tindak pidana pencucian uang haruslah diadili dalam peradilan umum sebagaimana telah ditentukan dalam Pasal 25 ayat (2) Undang-Undang No. 48 tahun 2009 tentang Kekuasaan Kehakiman yang menyebutkan "Peradilan umum sebagaimana dimaksud pada ayat (1) berwenang memeriksa, mengadili, dan memutus perkara pidana dan perdata sesuai dengan ketentuan peraturan perundangundangan", 4 dengan demikian terhadap perkara-perkara tindak pidana pencucian uang walaupun merupakan tindak pidana khusus, sampai dengan sekarang tidak ada pengadilan khususnya, maka kewenangan mengadili menjadi kewenangan peradilan umum.

\footnotetext{
${ }^{3}$ Undang-Undang No. 49 Tahun 2009 tentang perubahan atas Undang-Undang Nomor 8 Tahun 2004 tentang Perubahan Atas Undang-Undang Nomor 2 Tahun 1986 tentang kekuasaan kehakiman

${ }^{4}$ Undang-Undang Nomor 48 Tahun 2009 tentang Kekuasaan Kehakiman.
}

Dengan diundangkan nya UU No. 46 Tahun 2009 tentang Pengadilan tindak pidana korupsi, dalam pasal 6 huruf b UU No. 46 Tahun 2009, salah satu kewenangan Pengadilan Tindak Pidana korupsi adalah mengadili Tindak Pidana Pencucian Uang, yang tindak pidana asalnya adalah tindak pidana korupsi. Mencermati kewenangan tindak pidana korupsi tersebut, maka dapatlah disimpulkan bahwa kewenangan tersebut ditentukan "tindak pidana asal", dengan demikian kewenangan suatu peradilan dalam mengadili perkara selain ditentukan jenis perkaranyajuga ditentukan tindak pidana asal.

Sebagai tindak pidana lanjutan, ditegaskan dalam Pasal 2 ayat (1) UU Nomor 8 Tahun 2010 dinyatakan "hasil tindak pidana adalah harta kekayaan yang diperoleh dari tindak pidana:
a. Korupsi;
b. Penyuapan
c. Narkotika;
d. Psokotropika;
e. Penyeludupan tenaga kerja;
f. Penyeludupan migrant;
g. di bidang perbankan;
h. di bidang pasar modal;
i. di bidang perasuransian;
j. kepabeanan;
k. cukai;
1. perdagangan orang;
m. perdagangan senjata gelap;
n. terorisme;
o. penculikan;
p. pencurian;
q. penggelapan; 
r. penipuan;

s. pemalsuan uang;

t. perjudian;

u. prostitusi;

v. di bidang perpajakan;

w. di bidang kehutanan;

x. di bidang lingkungan hidup;

y. di bidang kelautan dan perikanan;atau

z. tindak pidana lain yang diancam dengan pidana penjara 4(empat) tahun ataulebih;

Dari 26 sumber hasil tindak pidana sebagaimana Pasal 2 ayat (1) UndangUndang No. 8 Tahun 2010 tentang pencegahan dan pemberantasan tindak pidana pencucian uang, salah satu sumber hasil tindak pidana pada huruf "a" adalah korupsi;

Menurut ketentuan Pasal 18 UndangUndang No. 48 tahun 2009 tentang Kekuasaan Kehakiman dilakukan oleh sebuah Mahkamah Agung dan badan peradilan yang berada di bawahnya dalam lingkungan peradilan umum, lingkungan peradilan agama, lingkungan peradilan militer, lingkungan peradilan tata usaha negara, dan oleh sebuah Mahkamah Konstitusi, lebih lanjut dalam Pasal 21 ayat (2) dinyatakan "Ketentuan mengenai organisasi, administrasi, dan finansial badan peradilan sebagaimana dimaksud pada ayat (1) untuk masing-masing lingkungan peradilan diatur dalam undang-undang sesuai dengan kekhususan lingkungan peradilan masing-masing".

Berdasarkan Pasal 1 ayat (8) Undangundang No. 48 tahun 2009, dinyatakan "Pengadilan Khusus adalah pengadilan yang mempunyai kewenangan untuk memeriksa, mengadili dan memutus perkara tertentu yang hanya dapat dibentuk dalam salah satu lingkungan badan peradilan yang berada di bawah Mahkamah Agung yang diatur dalam undang-undang". Lebih lanjut di dalam ketentuan Pasal 27 ayat (1) Undang-Undang No. 48 tahun 2009 jelas dinyatakan "Pengadilan khusus hanya dapat dibentuk dalam salah satu lingkungan peradilan yang berada di bawah Mahkamah Agung sebagaimana dimaksud dalam Pasal 25 , lebih lanjut dalam ayat (2) dinyatakan "Ketentuan mengenai pembentukan pengadilan khusus sebagaimana dimaksud pada ayat (1) diatur dalam undang-undang".

Secara yuridis konstitusional, keberadaan Pengadilan Tindak Pidana Korupsi berada pada salah satu dari 4 (empat) lingkungan peradilan, dalam hal ini di bawah lingkungan peradilan umum.

Pada pasal 5 Undang-undang Nomor 46 Tahun 2009 tentang Pengadilan Tindak Pidana Korupsi dinyatakan bahwa Pengadilan Tindak Pidana Korupsi merupakan satu-satunya pengadilan yang berwenang memeriksa, mengadili, dan memutus perkara tindak pidana korupsi, sehingga perkara korupsi mutlak menjadi wilayah yurisdiksi kewenangan Pengadilan Tindak Pidana Korupsi, hal ini sejalan dengan putusan Mahkamah Konstitusi No. 012-016-019/PUU/IV/2006 tanggal 19 Desember 2006 yakni untuk menghindari dualisme peradilan dan menjamin asas equality before the law karena perkara korupsi hanya menjadi ranah wilayah yurisdiksi Pengadilan Tindak Pidana Korupsi bukan lagi kewenangan peradilan umum dalam hal ini pengadilan negeri.

Tindak pidana pencucian uang adalah tindak pidana khusus yang pengaturannya di luar KUHP, sekarang diatur dalam Undang-Undang No. 8 Tahun 2010 tentang Pencegahan dan pemberantasan Tindak Pidana Pencucian Uang. Walaupun merupakan tindak pidana khusus, akan tetapi dalam mengadili setiap orang yang diduga sebagai pelaku tindak pidana tersebut dilakukan dalam lingkungan 
peradilan umum, tidak ada pengadilan khususnya. Untuk mengadili tindak pidana pencucian uang yang tindak pidana asalnya korupsi tentulah harus didasarkan kepada hukum acara (process law) yang mengaturnya. Berdasarkan Pasal 6 Undangundang No. 46 Tahun 2009 jika tindak pidana pencucian uang tersebut didahului adanya tindak pidana korupsi maka yang berwenang mengadili adalah pengadilan tindak pidana korupsi.

Dengan adanya 2 (dua) lembaga yang berwenang mengadili tindak pidana pencucian uang akan membawa dampak dalam penegakan hukum, kepastian hukum dan efektivitas penegakan hukum dalam mengadili tindak pidana pencucian uang yang didasarkan pada tindak pidana asal (predicate crime) dalam menentukan pengadilan mana yang berwenang untuk mengadili perkara tindak pidana pencucian uang.

Sebagai tindak pidana lanjutan tidak ada permasalahan hukum bila setiap orang yang diduga sebagai pelaku tindak pidana pencucian uang untuk diadili di pengadilan tanpa mengikutkan tindak pidana asalnya (predicate crime), akan tetapi yang menjadi masalah adalah pengadilan mana yang berwenang mengadili tindak pidana tersebut jika Penuntut Umum atau Komisi Pemberantasan Korupsi (KPK) melimpahkan perkara ke pengadilan dengan dakwaan nya tanpa mengikutkan tindak pidana asalnya (predicate crime) berdasarkan pasal 69 Undang-Undang Nomor 8 Tahun 2010 tentang pencegahan dan pemberantasan tindak pidana pencucian uang.

Penuntutan sebagaimana pasal 1 butir 7 Undang-Undang No. 8 Tahun 1981 tentang Hukum Acara Pidana didefinisikan sebagai "tindakan penuntut umum untuk melimpahkan perkara pidana ke pengadilan negeri yang berwenang dalam hal dan menurut cara yang diatur dalam undangundang ini dengan permintaan supaya diperiksa dan diputus oleh hakim di sidang pengadilan. "Perkara yang dilimpahkan itu diberkaskan dalam satu berkas perkara yang disertai surat dakwaan sebagai dasar pemeriksaan perkara di sidang pengadilan nanti". ${ }^{5}$

Untuk penyidikan, penuntutan, dan pemeriksaan perkara tindak pidana pencucian uang di sidang pengadilan diatur dalam Pasal 69 Undang-Undang Nomor 8 Tahun 2010 yang berbunyi "untuk dapat dilakukan penyidikan, penuntutan, dan pemeriksaan di sidang pengadilan terhadap tindak pidana pencucian uang tidak wajib dibuktikan terlebih dahulu tindak pidana asalnya". ${ }^{6}$

Sejalan dengan pemeriksaan perkara di pengadilan yang diatur dalam Pasal 69 Undang-Undang Nomor 8 Tahun 2010, dalam Pasal 143 ayat (1) KUHAP disyaratkan dalam hal "Penuntut Umum melimpahkan perkara ke Pengadilan Negeri dengan permintaan agar segera mengadili perkara tersebut disertai dengan surat dakwaan". Lebih lanjut dalam ayat (2) huruf "b" disyaratkan dalam hal "penuntut umum membuat surat dakwaan yang diberi tanggal dan ditandatangani serta berisi (b) "uraian secara cermat, jelas dan lengkap mengenai tindak pidana yang didakwakan dengan menyebutkan waktu dan tempat tindak pidana itu dilakukan". ${ }^{7}$

Mencermati Pasal 69 Undang-Undang Nomor 8 Tahun 2010 dan dihubungkan Pasal 143 ayat (1) dan ayat (2) huruf "b" KUHAP dapat disimpulkan bahwa agar pemeriksaan di sidang pengadilan dapat dilakukan haruslah didasarkan kepada dakwaan yang memuat uraian secara cermat, jelas dan lengkap mengenai

${ }^{5}$ Adami Chazawi, hukum pidana materil dan formil korupsi di Indonesia, Bayumedia Publishing, cet ketiga, Mei 2010, hlm 382

${ }^{6}$ Undang-Undang No. 8 Tahun 2010 tentang pencegahan dan pemberantasan tindak pidana pencucian uang

${ }^{7}$ Undang-Undang No. 8 Tahun 1981 tentang Hukum Acara Pidana 
tindak pidana yang didakwakan dengan menyebutkan waktu dan tempat tindak pidana itu dilakukan. Uraian secara cermat, jelas dan lengkap mengenai tindak pidana yang didakwakan tersebut bersifat imperatif karena dengan dasar itulah Pengadilan menetapkan apakah pengadilan yang bersangkutan berwenang untuk mengadili nya sebagaimana ditentukan dalam pasal 147 KUHAP yang menyatakan "setelah pengadilan negeri menerima surat pelimpahan perkara dari Penuntut Umum, ketua mempelajari apakah perkara itu termasuk wewenang pengadilan yang dipimpin nya", selanjutnya dalam pasal 148 ayat (1) KUHAP dinyatakan "dalam hal ketua pengadilan negeri berpendapat, bahwa perkara pidana itu tidak termasuk wewenang yang dipimpin nya, tetapi wewenang pengadilan negeri lain, ia menyerahkan surat pelimpahan perkara tersebut kepada pengadilan negeri lain yang dianggap berwenang mengadili nya dengan surat penetapan yang memuat alasannya. ${ }^{8}$

Berdasarkan uraian di atas, maka tulisan ini hendak mengkaji Apa dasar kewenangan Pengadilan tindak pidana korupsi dalam mengadili tindak pidana pencucian uang dan apa akibat hukum putusan pengadilan tindak pidana korupsi dalam mengadili tindak pidana pencucian uang yang didasarkan. sedangkan metode penelitian yang digunakan dalam penelitian ini adalah penelitian normatif.

\section{PEMBAHASAN}

\section{a. Dasar kewenangan Pengadilan Tindak Pidana Korupsi}

Salah satu kunci yang diperlukan untuk membangun sistem kenegaraan yang mampu mewujudkan cita-cita keadilan terletak pada persoalan kualitas kelembagaan hukum dan peradilan yang memerlukan perhatian serius sesuai dengan tuntutan

${ }^{8}$ Undang-Undang No. 8 Tahun 1981 tentang $\mathrm{Hu}$ kum Acara Pidana

472 IUS Kajian Hukum dan Keadilan perkembangan jaman. Struktur peradilan di negara kita dewasa ini makin membutuhkan penataan, termasuk di dalamnya melakukan konsolidasi yang sistematis dan ter pola dengan baik terhadap keberadaan berbagai bentuk peradilan khusus. ${ }^{9}$

Pengadilan tindak pidana korupsi adalah pengadilan khusus yang berada dalam lingkungan peradilan umum. Pada awalnya, Pengadilan Tindak Pidana Korupsi hanya dibentuk di Pengadilan Negeri Jakarta Pusat yang wilayah hukumnya meliputi seluruh wilayah Negara Kesatuan Republik Indonesia. Pembentukan Pengadilan ini didasarkan kepada Pasal 53 Undang-Undang No. 30 Tahun 2003 tentang Komisi Pemberantasan Tindak Pidana Korupsi, yang menyatakan: "Dengan Undang-undang ini dibentuk pengadilan tindak pidana korupsi yang bertugas dan berwenang memeriksa dan memutus tindak pidana korupsi yang penuntutan nya diajukan oleh Komisi Pemberantasan Korupsi (KPK)". Lebih lanjut dalam Pasal 55 dinyatakan:

Mengacu kepada rumusan Pasal 53 tersebut, kewenangan pengadilan tindak pidana korupsi hanyalah memutus tindak pidana korupsi, yang penuntutan nya hanya dilakukan oleh Komisi Pemberantasan Korupsi. Dengan demikian terdapat dualisme pengadilan yang mengadili perkara korupsi, yakni peradilan umum (Pengadilan Negeri) dan peradilan khusus (Pengadilan Tindak Pidana Korupsi) yang secara struktural juga peradilan di bawah lingkungan peradilan umum).

Putusan Mahkamah Konstitusi yang mensyaratkan pembentukan pengadilan Tindak Pidana Korupsi yang berwenang mengadili tindak pidana korupsi harus dengan Undang-Undang selaras dengan pendapat Prof. Dr. Philipus M. Hadjon, SH yang mengatakan "Pasal 24 Ayat (3) UUD 1945 menyatakan, "badan-badan lain yang

${ }_{9}^{9}$ Jimly Asshiddiqie, Makalah, Pengadilan khusus, Jakarta, Juli 2013, hlm. 5 
fungsinya berkaitan dengan Kekuasaan Kehakiman diatur dalam undang-undang". Berdasarkan ketentuan tersebut setiap pembentukan badan yang berkaitan dengan Kekuasaan Kehakiman (seperti Pengadilan Tindak Pidana Korupsi) harus secara tegas menyebutkan Pasal 24 Ayat (3) UUD 1945 sebagai dasar hukum. Hal itu harus dicantumkan dalam konsiderans mengingat (periksa Undang-Undang Nomor 10 Tahun 2004 tentang Proses Pembentukan Peraturan Perundang-undangan beserta lampiran nya). Dalam kaitan dengan isu a quo, konsiderans mengingat UU KPK tidak mencantumkan Pasal 24 Ayat (3) UUD 1945, dalam konsiderans mengingat. Dilihat dari judul UU KPK, seyogianya Undang-Undang tersebut hanya mengatur lembaga KPK dan tidak mengatur pembentukan Pengadilan Tipikor dalam Bab VII UU KPK."10

Untuk mengantisipasi kekosongan hukum akibat Putusan mahkamah Konstitusi tersebut, Mahkamah konstitusi telah memberikan jangka waktu paling lama tiga tahun, apabila dalam jangka waktu tiga tahun tidak dapat dipenuhi oleh pembuat undang-undang, maka ketentuan Pasal 53 UU KPK dengan sendirinya, demi hukum (van rechtswege) tidak mempunyai kekuatan hukum mengikat lagi. Sebelum terbentuknya DPR dan Pemerintahan baru hasil Pemilu 2009, perbaikan undang-undang dimaksud sudah harus diselesaikan dengan sebaikbaiknya guna memperkuat basis konstitusional upaya pemberantasan tindak pidana korupsi. Apabila pada saat jatuh tempo tiga tahun sejak putusan ini diucapkan tidak dilakukan penyelarasan UU KPK terhadap UUD 1945 khususnya tentang pembentukan Pengadilan Tipikor dengan undang-undang tersendiri, maka seluruh penanganan perkara tindak pidana korupsi menjadi wewenang pengadilan dalam lingkungan Peradilan Umum; ${ }^{11}$

\footnotetext{
${ }^{10}$ Ibid hlm 207

${ }^{11}$ Ibid, hal 209
}

Putusan Mahkamah Konstitusi sendiri di dalam putusannya memberikan berbagai pertimbangan yang diantaranya membentuk undang-undang tersendiri dalam proses peradilan tindak pidana korupsi. Dengan demikian, MK hanya memutuskan agar dasar hukum Pengadilan Tipikor diperkuat dengan membuat UU baru. MK juga menentukan waktu paling lama tiga tahun setelah putusan MK ini harus sudah ada Undang-Undang Pengadilan Tipikor yang baru.

Dalam Pasal 5 UU No. 46 Tahun 2009, jelas dinyatakan "Pengadilan Tindak Pidana Korupsi merupakan satu-satunya pengadilan yang berwenang memeriksa, mengadili dan memutus perkara tindak pidana korupsi". Sehingga perkara korupsi menjadi mutlak menjadi wilayah yurisdiksi kewenangan pengadilan tindak pidana korupsi. Sejalan dengan keputusan Mahkamah Konstitusi yakni untuk menghindari dualisme peradilan dan menjamin asas equality before the law yang mengandung maka setiap orang memiliki kedudukan yang sama di depan hukum karena perkara korupsi hanya menjadi ranah wilayah yurisdiksi pengadilan tindak pidana korupsi yang berada dalam lingkungan peradilan umum.

\section{b. Lingkup Kewenangan Pengadilan Tindak Pidana Korupsi secara Absolut.}

Negara Republik Indonesia yang berdasarkan Pancasila dan Undang-Undang Dasar Negara Republik Indonesia Tahun 1945, semestinya keadilan, ketertiban, kebenaran dan kepastian hukum dalam sistem dan penyelenggaraan hukum merupakan hal pokok yang sangat penting dalam usaha mewujudkan suasana perikehidupan yang aman, tentram dan tertib. Oleh karena itu untuk mewujudkan hal-hal tersebut dibutuhkan adanya lembaga yang bertugas untuk menyelenggarakan kekuasaan kehakiman guna menegakkan hukum dan keadilan dengan baik. Salah satu 
lembaga untuk menegakkan hukum dalam mencapai keadilan, kebenaran, ketertiban dan kepastian hukum adalah badan-badan peradilan sebagaimana yang dimaksud dalam Undang-undang Nomor 48 Tahun 2009 tentang Kekuasaan Kehakiman, yang masing-masing mempunyai lingkup kewenangan mengadili perkara atas sengketa di bidang tertentu.

Pengadilan Tindak pidana korupsi sebagai salah satu pelaku kekuasaan kehakiman mengalami perubahan strategis sebagai respon atas perkembangan hukum dan kebutuhan hukum masyarakat, utamanya terkait dengan pemberantasan korupsi. Pasca reformasi Kewenangan Peradilan Tindak pidana korupsi berada dalam ruang lingkup peradilan umum sebagaimana diatur dalam ketentuan Pasal 27 Ayat (1) Undang-Undang 48 Tahun 2009 tentang kekuasaan kehakiman.

Kemudian muncul Undang-Undang Nomor 46 Tahun 2009 tentang Pengadilan tindak pidana korupsi yang mengatur secara tegas mengatur kewenangan Pengadilan tindak pidana korupsi yang terdapat dalam Pasal5yangmenyatakan "Pengadilan Tindak Pidana Korupsi merupakan satu-satunya pengadilan yang berwenang memeriksa, mengadili, dan memutus perkara tindak pidana korupsi", ${ }^{12}$ Undang-undang Tindak Pidana korupsi ini membawa perubahan dimana kewenangan mengadili perkara korupsi yang sebelumnya berada dalam lingkungan peradilan umum beralih menjadi kewenangan pengadilan tindak pidana korupsi. Namun bila diteliti lebih lanjut, Kewenangan pengadilan tindak pidana korupsi ini ternyata ada perluasan kewenangan sebagaimana termuat dalam Pasal 6 UU Nomor 46 Tahun 2009, disebutkan Pengadilan Tindak Pidana Korupsi sebagaimana dimaksud dalam Pasal 5 berwenang memeriksa, mengadili, dan memutus perkara: (b) tindak pidana pencucian uang yang tindak

${ }^{12}$ Undang-Undang No. 46 Tahun 2009 tentang Pengadilan tindak pidana korupsi pidana asalnya adalah tindak pidana korupsi; dan/atau (c) tindak pidana yang secara tegas dalam undang-undang lain ditentukan sebagai tindak pidana korupsi. ${ }^{13}$

Sejak berlakunya Undang-undang Nomor 46 Tahun 2009, Kewenangan absolut Pengadilan Tindak pidana korupsi sebagai salah satu pelaku kekuasaan kehakiman mengalami perubahan strategis sebagai respon atas perkembangan hukum dan kebutuhan hukum masyarakat, utamanya terkait dengan pemberantasan korupsi. Undang-undang Tindak Pidana korupsi ini selain berwenang mengadili tindak pidana korupsi, ternyata ada perluasan kewenangan sebagaimana termuat dalam Pasal 6 UU Nomor 46 Tahun 2009, disebutkan Pengadilan Tindak Pidana Korupsi sebagaimana dimaksud dalam Pasal 5 berwenang memeriksa, mengadili, dan memutus perkara: (b) tindak pidana pencucian uang yang tindak pidana asalnya adalah tindak pidana korupsi; dan/atau (c) tindak pidana yang secara tegas dalam undang-undang lain ditentukan sebagai tindak pidana. ${ }^{14}$

Salah satu perluasan kewenangan pengadilan Tindak Pidana Korupsi yang diberikan oleh pembuat Undang-undang adalah mengadili tindak pidana Pencucian uang yang tindak pidana asalnya adalah tindak pidana korupsi.

Bila melihat latar belakang diundangkannnya UU No. 46 Tahun 2009, dalam Menimbang (Konsiderans) sebagai alasan filosofis, sosiologis dan Yuridis sama sekali tidak ada kaitannya dengan tindak pidana pencucian uang baik dari sisi hukum materilnya maupun hukum formil nya. Selanjutnya bagaimana dengan kewenangan Pengadilan tindak pidana Korupsi dalam mengadili tindak pidana penculikan uang yang tindak pidana asalnya korupsi yang

\footnotetext{
${ }^{13}$ Undang-Undang No. 46 Tahun 2009 tentang Pengadilan tindak pidana korupsi

14 Undang-Undang No. 46 Tahun 2009 tentang Pengadilan Tindak Pidana Korupsi
} 
pengaturannya dalam Pasal 6 UU No. 46 Tahun 2009.

Terkait dengan pemberian kewenangan terhadap badan-badan lain yang fungsinya berkaitan dengan kekuasaan kehakiman diatur dalam undang-undang, dengan demikian Pengadilan tindak pidana korupsi hanya berwenang mengadili tindak pidana korupsi sebagaimana telah ditentukan dalam Pasal 5 yang menyebutkan "Pengadilan tindak pidana korupsi merupakan satu-satunya pengadilan yang berwenang memeriksa, mengadili, dan memutus perkara tindak pidana korupsi", jika ada perluasan kewenangan haruslah diatur dalam Undang-Undang.

\section{c. Tindak pidana pencucian uang sebagai tindak pidana lanjutan (follow up crime)}

Sampai dengan saat ini, masih terjadi dualisme pandangan dari para ahli hukum terhadap keberadaan Tindak Pidana Pencucian Uang (TPPU), yaitu apakah Tindak Pidana Pencucian Uang (TPPU) merupakan tindak pidana yang berdiri sendiri atau tindak pidana yang merupakan turunan dari tindak pidana lainnya yang merupakan tindak pidana pokok.

Apabila membaca ketentuan Pasal 2 dari Undang-Undang Nomor 8 Tahun 2010 tentang pencegahan dan pemberantasan tindak pidana pencucian uang, maka dapat disimpulkan bahwa apa yang tercantum dalam pasal 2 tersebut merupakan tindak pidana pokok dari tindak pidana pencucian uang karena harta kekayaan yang menjadi objek tindak pidana pencucian uang adalah berasal dari tindak pidana sebagaimana pasal 2 tersebut, akan tetapi apabila dihubungkan dengan Pasal 69 menyebutkan bahwa "untuk dapat dilakukan penyidikan, penuntutan, dan pemeriksaan di sidang pengadilan terhadap tindak pidana pencucian uang tidak wajib dibuktikan terlebih dahulu tindak pidana asalnya. Ketentuan Pasal 69 ini pun di dalam penjelasannya hanya menyebutkan "cukup jelas" sehingga menimbulkan multi tafsir. Secara normatif sudah jelas, bahwa untuk memeriksa perkara Tindak Pidana Pencucian Uang (TPPU) tidak wajib dibuktikan terlebih dahulu tindak pidana asalnya, sebaliknya tidak ada satu pun pasal berkaitan dengan hukum acara yang mewajibkan untuk dibuktikan terlebih dahulu tindak pidana asal sebelum memeriksa Tindak Pidana Pencucian Uang (TPPU).

Selanjutnya terhadap Pasal 69 UU No. 8 Tahun 2010, telah pernah diajukan uji Materi oleh R.J. Soehandoyo, S.H.,M.H, dalam pertimbangan Mahkamah pada Putusan Nomor 90/PUU-XIII/2015 tanggal 5 April 2016 telah mengambil alih putusannya dalam perkara No. $77 /$ PUUXII/2014 tanggal 12 Pebruari 2014, dengan pertimbangan sebagai berikut:

- Bahwa permohonan Nomor 77/ PUU-XII/2014 adalah permohonan pengujian Pasal 2 ayat (2), Pasal 3, Pasal 4, Pasal 5 ayat (1), Pasal 69, Pasal 76 ayat (1), Pasal 77, Pasal 78 ayat (1) dan Pasal 95 UU 8/2010 dengan mengunakan dasar pengujian Pasal 1 ayat (3), Pasal 280 ayat (1), Pasal 28G ayat (1), Pasal $28 \mathrm{H}$ ayat (4) dan Pasal 281 ayat (1) UUO 1945. Meskipun demikian, terhadap pengujian Pasal 69 UU 8/2010, Permohonan Nomor 77/ PUU-XII/2014 hanya menggunakan Pasal 1 ayat (3) sebagai dasar pengujian. Sedangkan dalam perkara Pemohon, dasarpengujianyang digunakanadalah Pasal 1 ayat (3) dan Pasal 280 ayat (1) UUO1945. OalamPermohonanNomor 77/PUU-XII/2014, Pasal 280 ayat (1) UUO 1945 digunakan sebagai dasar pengujian terhadap Pasal 2 ayat (2), Pasal 3, Pasal 4 dan Pasal 5 ayat (1) UU 8/2010. Sehingga menurut Mahkamah dasar pengujian yang digunakan dalam Permohonan Nomor 77/PUU- 
XII/2014berbeda dengan permohonan aquo sebagaimana telah dijelaskan dalam bagian duduk Perkara.

- Bahwa selain itu, menurut Mahkamah, masalah konstitusionalitas permohonan Nomor 77/PUU-XII/2014berbeda dengan permohonan aquo. Dalam permohonan Nomor 77/PUU-XII/2014 kedudukan Akil Mochtar selaku Pemohon adalah sebagai tersangka dalam tindak pidana asal sekaligus dalam TPPU. Sedangkan dalam permohonanaquo, kedudukanPemohon sebagai Tersangka dalam perkara TPPU bukan sebagai pelaku tindak pidana asalnya. Oleh karena itu menurut Mahkamah permohonanPemohontidakbertentangan dengan Pasal 60 UU MK sehingga dapat dimohonkan pengujian kembali;

- Menimbang bahwa dalam Putusan Mahkamah Nomor 77/PUUXII/2014 Mahkamah memberikan pertimbangan antara lain sebagai berikut:

"menurut Mahkamah andaikata pelaku tindak pidana asalnya meninggal dunia berarti perkaranya menjadi gugur, maka si penerima pencucian uang tidak dapat dituntut sebab harus terlebih dahulu dibuktikan tindak pidana asalnya. Adalah suatu ketidakadilan bahwa seseorang yang sudah nyata menerima keuntungan dari tindak pidana pencucian uang tidak diproses pidana hanya karena tindak pidana asalnya belum dibuktikan lebih dahulu. Rakyat dan masyarakat Indonesia akan mengutuk bahwa seseorang yang nyata-nyata telah menerima keuntungan dari tindak pidana pencucian uang lalu lepas dari jeratan hukum hanya karena tindak pidana asalnya belum dibuktikan lebih dahulu, namun demikian tindak pidana pencucian uang memang tidak berdiri sendiri, tetapi harus adakaitannya dengan tindak pidana asal.
Bagaimana mungkin ada tindak pidana pencucian uang kalau tidak ada tindak pidana asalnya. Apabi/a tindak pidana asalnya tidak bisa dibuktikan terlebih dahulu, maka tidak menjadi halangan untuk mengadili tindak pidana pencucian uang. Meskipun tidak persis sama dengan tindak pidana pencucian uang dalam KUHP telah dikenal tindak pidana penadahan (vide Pasal 480 KUHP) yang dalam praktiknya sejak dahulu tindak pidana asalnya tidak perlu dibuktikan terlebih dahulu..."

Dalam pertimbangan Mahkamah pada Putusan Nomor 77/PUU-XII/2014 di atas jelas bahwa Mahkamah memandang tidak perlu dibuktikan terlebih dahulu pidana asal untuk dapat dilakukan penyidikan, penuntutan dan pemeriksaan di sidang pengadilan dalam perkara TPPU. Namun dalam pertimbangan tersebut Mahkamah juga menegaskan bahwa TPPU tidak berdiri sendiri tetapi ada kaitannya dengan tindak pidana asal, karena tidak mungkin ada TPPU tanpa ada tindak pidana asal. Untuk itu Mahkamah memandang perlu mempertimbangkan lebih lanjut mengenai kaitan antara tindak pidana asal dengan TPPU.

Menimbang bahwa pengertian TPPU dalam UU 8/2010 tidak hanya diartikan sempit pada pelaku yang aktif melakukan perbuatan menempatkan, mentransfer, mengalihkan, membelanjakan, membayarkan, menghibahkan, menitipkan, membawa ke luar negeri, mengubah bentuk, menukarkan dengan mata uang atau surat berharga atau perbuatan lain atas harta kekayaan yang diketahui nya atau patut diduganya merupakan hasil tindak pidana (Pasal 3 UU 8/2010), namun juga pelaku pasif yang hanya menyembunyikan atau menyamarkan asal usul, sumber lokasi, peruntukan, pengalihan hak-hak, atau kepemilikan yang sebenarnya (Pasal 4 UU 8/2010), termasuk juga yang hanya menerima, menguasai, dan 
menggunakan harta kekayaan dimaksud (Pasal 5 UU 8/2010);

Dengan pengertian di atas jelas bahwa tujuan pelaku melakukan TPPU bukan hanya menyembunyikan tetapi mengubah asal usul hasil kejahatan untuk tujuan selanjutnya dan menghilangkan hubungan langsung dengan kejahatan asalnya. Dengan demikian, dalam berbagai kejahatan keuangan bisa dipastikan dilakukan TPPU untuk menyembunyikan hasil kejahatan itu agar terhindar dari tuntutan hukum;

Menimbang bahwa TPPU adalah tindak pidana lanjutan (follow up crime) yang merupakan kelanjutan dari tindak pidana asal (predicate crime), sebagai sebuah upaya untuk menyembunyikan, atau menghilangkan jejak, sedemikian rupa sehingga tidak dapat diketahui bahwa harta kekayaan tersebut berasal dari tindak pidana. Sedangkan tindak pidana asal (predicate crime) merupakan tindak pidana yang menghasilkan uang/harta kekayaan yang kemudian dilakukan proses pencucian. Oleh karena itu tidaklah mungkin ada TPPU tanpa adanya tindak pidana asalnya terlebih dahulu;

Berbeda dengan tindak pidana lain, TPPU adalah tindak pidana yang tidak berdiri sendiri, namun didahului dan mungkin diikuti dengan tindak pidana lain. TPPU merupakan bagian dari serangkaian kejahatan yang saling berkaitan. Karena itulah rezim pemberantasan TPPU berprinsip follow the money, bukan follow the person, karena tindak pidananya yang saling terangkai mengalirkan harta kekayaannya dari tangan yang satu ke tangan yang lain;

Sebagai follow up crime, menurut Mahkamah untuk melakukan penyidikan, penuntutan, dan pemeriksaan dalam perkara TPPU tetap harus didahului dengan adanya tindak pidana asal, namun tindak pidana asal tersebut tidak wajib dibuktikan terlebih dahulu. Jadi frasa "tidak wajib dibuktikan terlebih dahulu" bukan berarti tidak perlu dibuktikan sama sekali, namun TPPU tidak perlu menunggu lama sampai perkara pidana asalnya diputus atau telah memperoleh kekuatan hukum tetap;

Menimbang bahwa, dalam praktiknya, dengan berlakunya ketentuan Pasal 69 UU 8/2010 penanganan perkara TPPU sangat mungkin akan selesai diperiksa dan diputus terlebih dahulu dari perkara tindak pidana asalnya. Terhadap dalil Pemohon yang menyatakan bahwa keadaan demikian tidak memberikan kepastian hukum, Mahkamah berpendapat bahwa hal itu merupakan masalah teknis yudisial dalam arti luas karena Pasal 75 UU 8/2010 telah mengatur penggabungan penyidikan tindak pidana asal dengan penyidikan TPPU dalam hal penyidik menemukan bukti permulaan yang cukup. Dengan teknik penggabungan ini, menurut Mahkamah, seharusnya perbedaan putusan yang mencolok antara TPPU dan tindak pidana asal dapat dihindari;

Apalagi dalam rezim penanganan TPPU juga dikenal pembalikan beban pembuktian sebagaimana diatur dalam Pasal 77 dan Pasal 78UU 8/2010, dimana untuk kepentingan pemeriksaan di pengadilan, terdakwa wajib membuktikan bahwa harta kekayaan nya bukan merupakan hasil tindak pidana. Pembalikan beban pembuktian ini, menurut Mahkamah, akan memudahkan penanganan perkara TPPU, meskipun yang wajib dibuktikan terdakwa hanyalah terkait perolehan objek perkara. Karena jika terdakwa tidak mampu membuktikan asal-usul perolehan harta kekayaan nya, berarti eksistensi dari tindak pidana asal sudah ada.

Menimbang bahwa, dalam perkembangannya, kejahatan semakin terorganisir, bahkan sampai melintasi batas yurisdiksi nasional negara-negara. Kejahatan terorganisir semakin didukung dengan teknologi yang berkembang pesat. Pemberantasan kejahatan ini semakin tertinggal jauh dari 
modus yang semakin variatif dan kompleks merambah berbagai sektor. TPPU menjadi jalan keluar bagi pelaku kejahatan untuk "menyelamatkan" harta kekayaan hasil kejahatannya dan menghindar dari jeratan hukum;

Untuk itu penegakan hukum dalam pemberantasan TPPU haruslah bergerak lebih cepat dari pemberantasan tindak pidana biasa, sebab jika tidak maka akan kehilangan jejak dan bukan hanya TPPU yang tidak dapat dibuktikan, tetapi tindak pidana lain yang berkaitan, termasuk tindak pidana asal, juga bisa kehilangan bukti. Jika demikian maka negara dan masyarakat akan sangat dirugikan, bukan hanya karena kerugian materil dari harta kekayaan yang telah dicuci, tetapi kerugian karena tidak terungkapnya kejahatan;

Sistem penanganan perkara TPPU yang diatur dalam UU 8/2010 sesungguhnya memberikan kemudahan dalam penegakannya. Pasal 69 UU 8/2010 menjadi salah satu ketentuan yang mempermudah dan mempercepat gerak penegak hukum dalam penanganan TPPU. Sebaliknya, jika dalam penanganan TPPU harus terlebih dahulu dibuktikan tindak pidana asal yang mungkin lebih rumit dalam pembuktian, terlebih apabila harus menunggu putusan yang telah berkekuatan hukum tetap, keadaan demikian akan menghabiskan waktu lama, sehingga penanganan perkara TPPU akan sangat terlambat, hal mana tidak bersesuaian dengan semangat UU 8/2010 untuk menangani TPPU dengan cepat dan tepat, serta akan memberi kesempatan kepada tersangka TPPU untuk menghilangkan jejak hasil tindak pidananya;

Oleh karena itu menurut Mahkamah ketentuan Pasal 69 yang mengatur bahwa untuk dapat dilakukan penyidikan, penuntutan, dan pemeriksaan di sidang pengadilan terhadap TPPU tidak wajib dibuktikan terlebih dahulu tindak pidana asalnya tidak bertentangan dengan UUD
1945 dan telah pula bersesuaian dengan semangat pemberantasan tindak pidana terorganisir.

Menimbang bahwa dengan pertimbangan hukum tersebut di atas Mahkamah berpendapat dalil permohonan Pemohon tidak beralasan menurut hukum. ${ }^{15}$

Terhadap Pasal 69 UU No. 8 Tahun 2010, telah pernah diajukan uji Materi oleh Akil Muchtar, dalam pertimbangan Mahkamah pada Putusan Mahkamah Konstitusi Nomor 77/PUU-XII/2014 tanggal 12 Pebruari 2014, Terkait dengan sikap Mahkamah konstitusi atas uji materi Pasal 69 UU No. 8 Tahun 2010 tentang pencegahan dan pemberantasan tindak pidana pencucian uang, apakah tindak pidana yang berdiri sendiri, menyatakan : "Menimbang bahwa mengenai tindak pidana pencucian uang, yang menurut Pasal 69 UU 8/2010 tidak wajib dibuktikan terlebih dahulu tindak pidana asalnya, yang oleh Pemohon di mohon supaya tindak pidana asalnya wajib dibuktikan terlebih dahulu, menurut Mahkamah andaikata pelaku tindak pidana asalnya meninggal dunia berarti perkaranya menjadi gugur, maka si penerima pencucian uang tidak dapat dituntut sebab harus terlebih dahulu dibuktikan tindak pidana asalnya. Adalah suatu ketidakadilan bahwa seseorang yang sudah nyata menerima keuntungan dari tindak pidana pencucian uang tidak diproses pidana hanya karena tindak pidana asalnya belum dibuktikan lebih dahulu. Rakyat dan masyarakat Indonesia akan mengutuk bahwa seseorang yang nyata-nyata telah menerima keuntungan dari tindak pidana pencucian uang lalu lepas dari jeratan hukum hanya karena tindak pidana asalnya belum dibuktikan lebih dahulu, namun demikian tindak pidana pencucian uang memang tidak berdiri sendiri, tetapi harus ada kaitannya dengan tindak pidana asal. Bagaima-

15 Putusan Mahkamah Konstitusi Nomor 77/PUUXII/2014 tanggal 12 Pebruari 2014, hlm. 204-205 
na mungkin ada tindak pidana pencucian uang kalau tidak ada tindak pidana asalnya. Apabila tindak pidana asalnya tidak bisa dibuktikan terlebih dahulu, maka tidak menjadi halangan untuk mengadili tindak pidana pencucian uang. Meskipun tidak persis sama dengan tindak pidana pencucian uang dalam KUHP telah dikenal tindak pidana penadahan (vide Pasal 480 KUHP) yang dalam praktiknya sejak dahulu tindak pidana asalnya tidak perlu dibuktikan terlebih dahulu. Berdasarkan pertimbangan di atas menurut Mahkamah dalil Pemohon a quo tidak beralasan menurut hukum. ${ }^{16}$

\section{d. Dakwaan sebagai dasar pemeriksaan perkara Tindak Pidana Pencucian Uang pada Pengadilan Tindak Pidana Korupsi.}

Pelimpahan perkara ke pengadilan didasarkan kepada hukum acara. Hukum acara pidana atau hukum pidana formil adalah seluruh ketentuan yang mengatur tentang bagaimana Negara dalam menegakkan hukum pidana materiil. ${ }^{17}$ Dalam hukum Pidana formil diatur tentang berbagai pekerjaan atau kegiatan dari lembaga-lembaga Negara yang wajib dan boleh dilakukan berhubungan dengan upaya penegakan hukum pidana materiil, yang dapat dikelompokkan ke dalam tiga kegiatan pokok atau kegiatan besar, yaitu (1). Kegiatan dalam penyidikan, (2) kegiatan dalam penuntutan, dan (3). Kegiatan dalam pemeriksaan di sidang pengadilan. ${ }^{18}$

Dakwaan sangat penting karena menjadi dasar pemeriksaan di sidang pengadilan dan yang kemudian juga menjadi dasar putusan hakim. Pemeriksaan dan putusan hakim tersebut terbatas pada apa yang didakwakan oleh penuntut umum. ${ }^{19}$ Memang

16 Putusan Mahkamah Konstitusi No. 99/PUUXIII/2015 tanggal 5 April 2016

${ }^{17}$ Adami Chazawi, hukum pidana materil dan formil Korupsi di Indonesia, Bayu Media Publishing, Malang, 2010, hlm 377

${ }^{18}$ Ibid, hlm 379

19 A. Hamzah dan Irdan Dahlan, Surat Dakwaan, Alumni, Bandung, 1987, hlm. 124
Penuntut Umum adalah penentu mengenai delik apa saja yang didakwakan kepada terdakwa. Ia disebut sebagai pemilik perkara atau tuntutan (dominus litis).

Hukum acara yang digunakan untuk pemeriksaan di sidang Pengadilan secara tegas dikatakan dalam Pasal 68 UndangUndang Nomor 8 Tahun 2010 tentang pencegahan dan pemberantasan tindak pidana pencucian uang, yakni:

"Penyidikan, penuntutan, dan pemeriksaan di sidang pengadilan serta pelaksanaan putusan yang telah memperoleh kekuatan hukum tetap terhadap tindak pidana sebagaimana dimaksud dalam undang-undang ini dilakukan sesuai dengan ketentuan peraturan perundangundangan, kecuali ditentukan lain dalam undang-undang ini"

Setelah penuntut umum menentukan bahwa hasil pemeriksaan penyidikan dapat dilakukan penuntutan, ia dalam waktu secepatnya membuat surat dakwaan. Adapun setiap penuntut umum melimpahkan perkara ke pengadilan selalu disertai dengan surat dakwaan sebagai dasar pemeriksaan yang dilakukan oleh hakim di pengadilan. ${ }^{20}$

Untuk mengadili tindak pidana pencucian uang Pasal 69 Undang-Undang Nomor 8 Tahun 2010 menyebutkan "untuk dapat dilakukan penyidikan, penuntutan, dan pemeriksaan di sidang pengadilan terhadap tindak pidana pencucian uang tidak wajib dibuktikan terlebih dahulu tindak pidana asalnya". Pada uraian pasal tersebut terdapat kalimat yang menyatakan "dan pemeriksaan di sidang pengadilan terhadap tindak pidana pencucian uang tidak wajib dibuktikan terlebih dahulu tindak pidana asalnya". Frasa dan pemeriksaan di sidang pengadilan terhadap tindak pidana pencucian uang tidak wajib dibuktikan terlebih dahulu tindak pidana asalnya" dapat diarti-

\footnotetext{
${ }^{20}$ Rusdi Muhammad, Hukum Acara Pidana Kontemporer, PT. Citra Aditya Bakti, Bandung, 2007, hlm 83.
} 
kan bahwa tindak pidana pencucian uang yang dilimpahkan ke pengadilan untuk disidangkan hanya didasarkan kepada sifat dari tindak pidana pencucian uang tersebut sebagai tindak pidana lanjutan tanpa harus mengikutkan tindak pidana asalnya yang harus diadili dalam lingkungan peradilan umum, sedangkan untuk mengadili perkara tindak pidana pencucian uang terdapat 2 pengadilan yang berwenang mengadilinya. Adanya 2 (dua) lembaga yang berwenang mengadili tindak pidana pencucian uang akan menimbulkan pertanyaan, "Pengadilan manakah secara absolut yang akan mengadili perkara tindak pidana pencucian uang apabila tidak disertakan dengan tindak pidana asalnya". Tegas dalam ketentuan Pasal 69 Undang-undang Nomor 8 Tahun 2010 yang berbunyi "untuk dapat dilakukan penyidikan, penuntutan, dan pemeriksaan di sidang pengadilan terhadap tindak pidana pencucian uang tidak wajib dibuktikan terlebih dahulu tindak pidana asalnya". ${ }^{21}$

Pemeriksaan perkara diatur dalam Pasal 69 Undang-Undang Nomor 8 Tahun 2010, dalam Pasal 143 ayat (1) KUHAP disyaratkan dalam hal "Penuntut Umum melimpahkan perkara ke Pengadilan Negeri dengan permintaan agar segera mengadili perkara tersebut disertai dengan surat dakwaan". Lebih lanjut dalam ayat (2) huruf "b" disyaratkan dalam hal "penuntut umum membuat surat dakwaan yang diberi tanggal dan ditandatangani serta berisi (b) "uraian secara cermat, jelas dan lengkap mengenai tindak pidana yang didakwakan dengan menyebutkan waktu dan tempat tindak pidana itu dilakukan". ${ }^{22}$

Mencermati Pasal 69 Undang-Undang Nomor 8 Tahun 2010 dan dihubungkan Pasal 143 ayat (1) dan ayat (2) huruf "b" KUHAP dapat disimpulkan bahwa agar

\footnotetext{
${ }^{21}$ Undang-Undang No. 8 Tahun 2010 tentang pencegahan dan pemberantasan tindak pidana pencucian uang

${ }^{22}$ Undang-Undang Nomor 8 Tahun 1981 tentang KUHAP
}

pemeriksaan di sidang pengadilan dapat dilakukan haruslah didasarkan kepada dakwaan yang memuat uraian secara cermat, jelas dan lengkap mengenai tindak pidana yang didakwakan dengan menyebutkan waktu dan tempat tindak pidana itu dilakukan. Uraian secara cermat, jelas dan lengkap mengenai tindak pidana yang didakwakan tersebut bersifat imperatif karena dengan dasar itulah Pengadilan menetapkan apakah pengadilan yang bersangkutan berkompeten untuk mengadili nya sebagaimana ditentukan dalam pasal 147 KUHAP yang menyatakan "setelah pengadilan negeri menerima surat pelimpahan perkara dari Penuntut Umum, ketua mempelajari apakah perkara itu termasuk wewenang pengadilan yang dipimpin nya", selanjutnya dalam pasal 148 ayat (1) KUHAP dinyatakan "dalam hal ketua pengadilan negeri berpendapat, bahwa perkara pidana itu tidak termasuk wewenang yang dipimpin nya, tetapi wewenang pengadilan negeri lain, ia menyerahkan surat pelimpahan perkara tersebut kepada pengadilan negeri lain yang dianggap berwenang mengadilinya dengan surat penetapan yang memuat alasannya.

Bahwa penetapan Ketua pengadilan dalam menetapkan apakah pengadilan negeri yang dipimpinya berwenang mengadili perkara tentulah berdasarkan surat dakwaan Penuntut umum yang harus memenuhi syarat sebagaimana Pasal 143 aya (2) huruf "b" KUHAP, salah satunya harus menyebutkan tempat pidana itu (locus delicty) dilakukan, sehingga ketua pengadilan mengeluarkan penetapan bahwa secara relative perkara tersebut diadili dalam pengadilan negeri yang dipimpinnya atau pengadilan negeri lain.

Ketentuan acara tersebut dalam pasal 69 Undang-Undang Nomor 8 Tahun 2010, Pasal 143 ayat (1) ayat (2) huruf "b", pasal 147 dan 148 KUHAP tersebut berlaku juga dalam pengadilan tindak pidana korupsi yang secara absolut berwenang mengadili 
tindak pidana pencucian uang yang tindak pidana asalnya korupsi. Bila surat dakwaan yang menjadi dasar menetapkan apakah suatu pengadilan berkompeten mengadili perkara, dalam pasal 143 ayat (2) huruf "b" juga jelas dinyatakan bahwa dakwaan harus memuat "uraian secara cermat, jelas dan lengkap mengenai tindak pidana yang didakwakan", hal ini juga menjadi dasar hukum yang menentukan apakah secara absolut suatu pengadilan berkompeten untuk mengadili perkara yang dilimpahkan ke pengadilan.

Kewenangan pengadilan tindak pidana korupsi diatur dalam Pasal 6 UndangUndang Nomor 46 Tahun 2009 tentang Pengadilan Tindak pidana korupsi, yang berbunyi :

"Pengadilan tindak pidana korupsi sebagaimana dimaksud dalam pasal 5 berwenang memeriksa, mengadili, dan memutus perkara:

a) Tindak pidana korupsi;

b) Tindak pidana pencucian uang yang tindak pidana asalnya adalah tindak pidana korupsi;dan/atau

c) Tindak pidana yang secara tegas dalam undang-undang lain ditentukan sebagai tindak pidana korupsi";

Salah satu kewenangan Pengadilan tindak pidana korupsi dalam Pasal 6 huruf "b" Undang-Undang Nomor 46 Tahun 2009 tentang Pengadilan Tindak pidana korupsi adalah memeriksa, mengadili, dan memutus perkara Tindak pidana pencucian uang yang tindak pidana asalnya adalah tindak pidana korupsi. Adanya kalimat yang menyatakan "yang tindak pidana asalnya adalah tindak pidana korupsi" adalah menjadi dasar kewenangan secara absolut Pengadilan Tindak Pidana Korupsi untuk mengadili perkara tersebut, karena di luar tindak pidana asalnya korupsi secara absolut menjadi kewenangan pengadilan negeri, sehingga untuk menjamin kepastian hukum Kejaksaan atau Komisi Pemberantasan Korupsi (KPK) dalam melimpahkan perkara pencucian uang yang tindak pidana asalnya korupsi haruslah mengikutkan tindak pidana asalnya Korupsi agar tidak menimbulkan akibat hukum batal demi hukum atau tidak ada kepastian hukum, karena kepastian hukum secara normatif harus jelas dalam artian tidak menimbulkan keragu-raguan (multi tafsir) dan logis dalam artian ia menjadi suatu system norma dengan norma lain sehingga tidak berbenturan atau tidak menimbulkan kontestasi norma, reduksi norma atau distorsi norma.

\section{e. Akibat hukum yang ditimbulkan atas Putusan Hakim Tindak pidana Ko- rupsi berdasarkan Pasal 69 UU No. 8 Tahun 2010 tentang pencegahan dan pemberantasan tindak pidana pencu- cian uang.}

Tujuan dari negara yang menganut sistem negara hukum adalah untuk mencapai suatu kehidupan yang adil dan makmur bagi warganya, yang berdasarkan kepada Ketuhanan Yang Maha Esa. Salah satu usaha untuk mencapai tujuan tersebut adalah menempatkan masalah hukum pada kedudukan yang sesungguhnya, sesuai dengan aturan yang berlaku dalam negara. Dalam hal ini hukum di negara Indonesia dijadikan suatu kaidah atau norma yang telah disepakati bersama dan karenanya harus dipertahankan dan ditaati bersama pula, baik itu oleh pemerintah maupun masyarakat dalam melaksanakan hak dan kewajiban masing-masing. Dalam suatu negara hukum seperti di Indonesia, Pengadilan adalah suatu badan atau lembaga peradilan yang merupakan tumpuan harapan untuk memperoleh keadilan. Oleh karena itu jalan yang terbaik untuk mendapatkan penyelesaian suatu perkara dalam negara hukum adalah melalui lembaga peradilan tersebut. Dalam suatu lembaga peradilan, hakim memegang peranan penting karena hakim dalam 
hal ini bertindak sebagai penentu untuk memutuskan suatu perkara yang diajukan ke pengadilan. Suatu putusan hakim mengandung perintah kepada suatu pihak supaya melakukan suatu perbuatan atau supaya jangan melakukan suatu perbuatan.

Kewenangan hakim dalam memutus perkara telah diatur dalam Undang-Undang Nomor 48 Tahun 2009 tentang kekuasaan kehakiman. Undang-undang ini diberlakukan dilatarbelakangi pertimbangan bahwa kekuasaan kehakiman menurut UndangUndang Dasar Tahun 1945 merupakan kekuasaan yang merdeka yang dilakukan oleh sebuah Mahkamah Agung dan badan peradilan di bawahnya dalam lingkungan peradilan umum, lingkungan peradilan agama, lingkungan peradilan militer. Lingkungan peradilan Tata Usaha Negara, dan oleh sebuah Mahkamah Konstitusi, untuk menyelenggarakan peradilan guna menegakkan hukum dan keadilan.

Putusan Pengadilan merupakan out put dari suatu proses peradilan di sidang pengadilan yang meliputi proses pemeriksaan saksi-saksi, pemeriksaan terdakwa, dan pemeriksaan barang bukti. Ketika proses pembuktian dinyatakan selesai oleh hakim, tiba lah saatnya hakim mengambil keputusan.

Dengan adanya dualisme kewenangan pengadilan dalam mengadili perkara Tindak pidana pencucian uang yang kewenangan absolutnya ditentukan oleh Tindak Pidana asal, dan pemeriksaan nya tidak mengikutkan tindak pidana asalnya, sangat dimungkinkan akan ada putusan pengadilan tindak pidana korupsi diketahui kemudian salah kewenangan.

Bahwa Putusan batal demi hukum tidak hanya menyangkut dengan ketentuan Pasal 197 KUHAP tetapi termasuk juga dengan adanya kesalahan kewenangan atau secara umum pelanggan yang terjadi terhadap hukum acara karena kekhilafan hakim;
Dengan adanya dua lembaga peradilan yang mempunyai kewenangan untuk mengadili tindak pidana pencucian uang, maka secara khusus hukum acara yang digunakan dalam pengadilan tindak pidana korupsi adalah hukum acara yang termuat dalam Undang-Undang No. 46 Tahun 2009.

Dalam uraian komposisi hakim di atas, salah satu kekhususan majelis hakim pengadilan tindak pidana korupsi adalah komposisi Majelis dalam mengadili perkara, yakni campuran hakim karier dan hakim adhoc, dengan kata lain setiap perkara yang menjadi kewenangan pengadilan tindak pidana korupsi harus diadili oleh Majelis hakim yang terdiri dari hakim karier dan hakim adhoc. Bila dikaitkan dengan kewenangannya, maka Majelis Hakim tindak pidana korupsi dalam mengadili tindak pidana pencucian uang sesuai hukum acaranya harus juga diadili dengan komposisi hakim secara kombinasi yakni hakim karier dan hakim adhoc.

Apabila dikaitkan dengan kewenangan, jika ternyata terhadap putusan Majelis hakim tindak pidana korupsi yang mengadili tindak pidana pencucian uang kemudian diketahui bahwa tindak pidana asalnya bukan korupsi, maka secara formal dapat disimpulkan bahwa Majelis hakim yang mengadili perkara tersebut tidak mempunyai kewenangan dengan demikian putusan tersebut telah menyalahi ketentuan hukum acara sehingga akibat hukumnya adalah batal demi hukum.

\section{f. Upaya hukum terhadap putusan Pengadilan (Pengadilan Tindak pidana Korupsi) yang batal demi hukum.}

Upaya hukum menurut hukum acara pidana dibedakan secara tegas dalam $\mathrm{Bab}$ XVII Pasal 233 KUHAP sampai dengan Pasal 258 KUHAP yang mengatur tentang upaya hukum biasa, dan Bab XVIII Pasal 259 KUHAP sampai dengan Pasal 269 KUHAP 
mengatur tentang upaya hukum luar biasa. Peninjauan kembali dalam KUHAP meruapkan salah satu upaya hukum luar biasa yang diatur dalam Pasal 263 KUHAP sampai dengan Pasal 269 KUHAP; sedangkan upaya hukum luar biasa yang lain adalah kasasi demi kepentingan hukum yang diatur dalam Pasal 259 KUHAP sampai dengan Pasal 262 KUHAP. Pasal 263 ayat (1) KUHAP telah menentukan bahwa terhadap putusan pengadilan yang telah memperoleh kekuatan hukum tetap, kecuali putusan bebas atau lepas dari segala tuntutan hukum, Terpidana atau ahli warisnya dapat mengajukan permintaan peninjauan kembali kepada Mahkamah Agung. ${ }^{23}$

Setelah proses pemeriksaan perkara di sidang pengadilan selesai maka hakim akan menjatuhkan putusan. Dalam menjatuhkan putusan, Hakim tidak luput dari kekeliruan atau kekhilafan, bahkan terkadang juga bersifat memihak maka oleh karena itu demi kebenaran dan keadilan setiap putusan Hakim dimungkinkan untuk diperiksa ulang melalui upaya hukum.

Menurut Pasal 1 angka 12 KUHAP "Upaya Hukum adalah hak terdakwa atau penuntut umum untuk tidak menerima putusan pengadilan yang berupa perlawanan atau banding atau kasasi atau hak terpidana untuk mengajukan permohonan peninjauan kembali dalam hal serta menurut cara yang diatur dalam undang-undang.

Terhadap putusan yang telah berkekuatan hukum tetap (inkrach van gewijde) diatur secara Khusus dalam Kitab Undangundang Hukum Acara Pidana (KUHAP) dari Pasal 263 sampai dengan Pasal 269. Permintaan Peninjauan Kembali (PK) sebagaimana telah diatur dalam Pasal 263 ayat (1) KUHAP.

Berdasarkan ketentuan dalam KUHAP, upaya hukum yang dapat dilakukan

${ }^{23}$ Undang-Undang Nomor 8 Tahun 1981 tentang Hukum Acara Pidana. terhadap putusan yang berkekuatan hukum tetap hanyalah peninjauan kembali.

Alasan pengajuan upaya hukum Peninjauan Kembali (PK), secara limitatif telah diatur Pasal 263 ayat (2) KUHAP, salah satunya diantaranya adalah "Apabila putusan itu dengan jelas memperlihatkan suatu kekhilafan hakim suatu kekeliruan nyata". Dalam penjelasannya ayat (2) dinyatakan kecuali yang tersebut pada huruf a, e, f dan $h$ apabila terjadi kekhilafan dan atau kekeliruan penulisan atau pengetikan tidak menyebabkan batal nya putusan demi hukum. Adapun ketentuan yang dimaksudkan dalam huruf $\mathrm{a}, \mathrm{e}, \mathrm{f}$ dan $\mathrm{h}$ tersebut adalah: a. Kepala putus putusan yang dituliskan berbunyi : "DEMI KEADILAN BERDASARKAN KETUHANAN YANG MAHA ESA", e. Tuntutan pidana, sebagaimana terdapat dalam surat tuntutan, f. Pasal peraturan perundang-undangan yang menjadi dasar hukum dari putusan, disertai keadaan yang memberatkan dan meringankan terdakwa dan h. Pernyataan kesalahan terdakwa, pernyataan telah dipenuhinya semua unsur dalam tindak pidana disertai dengan kualifikasi nya dan pemidanaan atau tindakan yang dijatuhkan. Dalam penjelasan tersebut tidak ada dijelaskan terkait dengan kesalahan kewenangan.

Mengajukan PK dengan alasan ada kekhilafan hakim atau kekeliruan nyata diatur dalam Pasal 67 huruf $f$ Undang-Undang No. 14 Tahun 1985 jo Undang-Undang 5 Tahun 2004 jo Undang-Undang No. 3 Tahun 2009 tentang Mahkamah Agung (UUMA). Berdasarkan pasal ini, permohonan PK dapat diajukan antara lain jika "dalam suatu putusan terdapat kekhilafan hakim atau suatu kekeliruan yang nyata".

\section{SIMPULAN}

Perluasan kewenangan Pengadilan Tindak Pidana Korupsi dalam mengadili tindak pidana pencucian uang berdasarkan Pasal 6 UU No. 46 Tahun 2009 tentang 
pengadilan tindak pidana korupsi tidak mempunyai dasar hukum yang kuat;

Pasal 69 UU 8 Tahun 2010 sebagai dasar hukum pemeriksaan perkara tindak pidana pencucian uang di sidang pengadilan tindak pidana korupsi merupakan norma kabur, karena norma ini selain berkaitan dengan pemeriksaan di sidang pengadilan tetapi berkaitan pula dengan kewenangan sebagai konsekwensi adanya perluasan kewenangan pengadilan tindak pidana korupsi dalam mengadili tindak pidana pencucian uang yang asalnya tindak pidana korupsi, dan mengakibatkan putusan hakim pengadilan tindak pidana korupsi yang mengadili perkara Tindak pidana Pencucian uang berdasarkan Pasal 69 UU No. 8 Tahun 2010 akan batal demi hukum;

\section{DAFTAR PUSTAKA}

Undang-Undang Nomor 8 tahun 2010 tentang pencegahan dan pemberantasan tindak pidana pencucian Uang.

Redaksi Bumi Aksara, KUHAP Lengkap, Bumi Aksara, Jakarta, 2001, hal. 204

Undang-Undang No. 49 Tahun 2009 tentang perubahan atas Undang-Undang Nomor 8 Tahun 2004 tentang Perubahan Atas Undang-Undang Nomor 2 Tahun 1986 tentang kekuasaan kehakiman

Undang-Undang Nomor 48 Tahun 2009 tentang Kekuasaan Kehakiman.

Adami Chazawi, hukum pidana materil dan formil korupsi di Indonesia, Bayumedia Publishing, cet ketiga, Mei 2010, hlm 382

Undang-Undang No. 8 Tahun 2010 tentang pencegahan dan pemberantasan tindak pidana pencucian uang

Undang-Undang No. 8 Tahun 1981 tentang Hukum Acara Pidana

Undang-Undang No. 8 Tahun 1981 tentang
Hukum Acara Pidana

Amiruddin \& Zainal Asikin, Pengantar Metode Penelitian Hukum, cetakan kedelapan, Rajawali Pers, 2014, hlm 118.

B. Arif Sidharta (penerjemah,) Meuwwisen tentang pengembangan, ilmu hukum, Teori Hukum dan Fisafat Hukum, Bandung, PT. Rafika Aditama, hlm 56-57).

Jimly Asshiddiqie, Makalah, Pengadilan khusus, Jakarta, Juli 2013, hlm. 5

Undang-Undang No. 46 Tahun 2009 tentang Pengadilan tindak pidana korupsi

Undang-Undang No. 46 Tahun 2009 tentang Pengadilan tindak pidana korupsi

Undang-Undang No. 46 Tahun 2009 tentang Pengadilan Tindak Pidana Korupsi

Putusan Mahkamah Konstitusi Nomor 77/ PUU-XII/2014 tanggal 12 Pebruari 2014, hlm. 204-205

Putusan Mahkamah Konstitusi No. 99/ PUU-XIII/2015 tanggal 5 April 2016

Adami Chazawi, hukum pidana materil dan formil Korupsi di Indonesia, Bayu Media Publishing, Malang, 2010, hlm 377

A. Hamzah dan Irdan Dahlan, Surat Dakwaan, Alumni, Bandung, 1987, hlm. 124

Rusdi Muhammad, Hukum Acara Pidana Kontemporer, PT. Citra Aditya Bakti, Bandung, 2007, hlm 83.

Undang-Undang No. 8 Tahun 2010 tentang pencegahan dan pemberantasan tindak pidana pencucian uang

Undang-Undang Nomor 8 Tahun 1981 tentang KUHAP

Undang-Undang Nomor 8 Tahun 1981 tentang Hukum Acara Pidana. 